\title{
STUDY ON ALTERNATIVE FUELS FOR LIME KILN IN A KRAFT PULP MILL VIA DIRECT COMBUSTION AND GASIFICATION
}

\author{
Syamsudin ${ }^{\text {a }} 1$, Herri Susanto ${ }^{\text {a } 2}$ \\ ${ }^{a}$ Chemical Engineering Department, Faculty of Industrial Technology \\ Insitut Teknologi Bandung, Jl. Ganesha 10, Bandung, Indonesia \\ ${ }^{\mathrm{b}}$ Center for Pulp and Paper, Jl. Raya Dayeuhkolot 132, Bandung 40258, Indonesia \\ ${ }^{1}$ syamsudin@kemenperin.go.id, ${ }^{2}$ herri@che.itb.ac.id
}

Diterima : 26 Maret 2013, Revisi akhir : 16 Mei 2013, Disetujui terbit : 30 Mei 2013

\section{STUDI BAHAN BAKAR ALTERNATIF UNTUK LIME KILN DI PABRIK PULP KRAFT MELALUI PROSES PEMBAKARAN LANGSUNG DAN GASIFIKASI}

\begin{abstract}
ABSTRAK
Bahan bakar lime kiln umumnya berupa gas alam. Keterbatasan cadangan dan peningkatan harga gas alam mendorong pabrik pulp memanfaatkan sumber energi alternatif seperti batubara dan biomassa. Bahan bakar ini dapat diimplementasikan melalui pembakaran langsung atau melalui proses gasifikasi. Lumpur sebanyak $95 \mathrm{~kg} /$ ton $\mathrm{CaO}$ merupakan biomassa yang tersedia di pabrik pulp. Lumpur ini memiliki nilai kalor $14 \mathrm{MJ} / \mathrm{kg}$ (basis kering). Cangkang sawit merupakan biomassa alternatif dengan nilai kalor $21 \mathrm{MJ} / \mathrm{kg}$. Batubara, meskipun termasuk sumber tidak-terbarukan, memiliki nilai kalor $25 \mathrm{MJ} / \mathrm{kg}$. Pada produksi $\mathrm{CaO}$ sebesar 380 ton/hari, pembakaran langsung lumpur mengurangi konsumsi gas alam 20\% dan lebih tinggi untuk batubara dan cangkang sawit. Penggantian gas alam ini dibatasi ketersediaan lumpur dan suhu pembakaran yang dicapai. Penggantian gas alam dengan batubara dan cangkang sawit lebih fleksibel dalam ketersediaan dan energi yang diperoleh. Tergantung medium gasifikasi dan konfigurasi reaktor, gas hasil gasifikasi dapat mencapai nilai kalor $11 \mathrm{MJ} / \mathrm{Nm}^{3}$ (lumpur kering), 18 $\mathrm{MJ} / \mathrm{Nm}^{3}$ (cangkang sawit), dan $19 \mathrm{MJ} / \mathrm{Nm}^{3}$ (batubara). Berbeda dengan pembakaran langsung bahan bakar padat, gas hasil gasifikasi dapat digunakan dengan sedikit modifikasi burner dan hasil pembakaran yang lebih bersih. Pembakaran gas hasil gasifikasi lumpur dapat mengurangi konsumsi gas alam 18\% dan lebih tinggi lagi untuk gas hasil gasifikasi batubara dan cangkang sawit.
\end{abstract}

Kata kunci: lumpur, cangkang sawit, batubara, pembakaran, gasifikasi, lime kiln

\begin{abstract}
Most common lime reburning kiln fuels are natural gas. Limiting gas and increasing its prices encourage pulp mills to find other types of energy resources such as coal and biomass. The use of those solid energy resources may be implemented through a direct solid combustion or via gasification process. Sludge about $95 \mathrm{~kg} / \mathrm{ton} \mathrm{CaO}$ available in the pulp mill. The sludge has a heating value of 14 $\mathrm{MJ} / \mathrm{kg}$ (dry basis). The palm nut shell has a heating value of $21 \mathrm{MJ} / \mathrm{kg}$. Coal, although it is belong to the category of non-renewable recources, has a heating value of $25 \mathrm{MJ} / \mathrm{kg}$. In production rate of $\mathrm{CaO}$ about 380 ton/day, direct combustion of natural gas with sludge cake reduce the natural gas consumption by $20 \%$ and higher for coal and palm nut shell. The portion natural gas substitution is limited by the availability of sludge and the attainable combustion temperature. Portion of coal and palm nut shell may be more flexible in term of availability and energy. Depending on gasifying agents and reactor configuration, the gaseous product of gasification may have a heating value of $11 \mathrm{MJ} / \mathrm{Nm}^{3}$ (sludge cake), $18 \mathrm{MJ} / \mathrm{Nm}^{3}$ (palm nut shell), and $19 \mathrm{MJ} / \mathrm{Nm}^{3}$ (coal). In contrast to direct combustion of solid fuel, the gaseous product of gasification may be used with a less modification of the burner and has cleaner combustion. Co-combustion of gaseous fuel from sludge may reduce the natural gas consumption by $18 \%$ and higher for gaseous fuel from coal and palm nut shell.
\end{abstract}

Keywords: sludge cake, palm nut shell, coal, co-combustion, gasification, lime kiln 


\section{INTRODUCTION}

Kraft pulp mill is one of the industrial sectors that consume large amounts of energy. In the last decade, limited reserves of natural gas and rising its price have prompted mills to look at cheaper alternatives energy such a readily available biomass waste in the mills. This effort is in line with Indonesia primary energy mix by year of 2025, where the renewable energy accounted for $17 \%$ of national energy demand (Kementerian Energi dan Sumber Daya Mineral, 2012). The $\mathrm{CO}_{2}$ emission mitigation is also currently one of the main environment issues. One possible of strategies to reduce $\mathrm{CO}_{2}$ emissions is based on the introduction of biomass as a substitute for fossil energy resources (Gustavsson and Svenningsson, 1996). Substituting biomass for fossil fuels in electricity and heat production is, in general, less costly and provides larger $\mathrm{CO}_{2}$ reduction per unit of biomass (Gustavsson, et al., 1995). The most important advantage of biomass fuels as compared to fossil fuels is that their thermal utilization is almost $\mathrm{CO}_{2}$ neutral, i.e. the $\mathrm{CO}_{2}$ emission in the product life is the same as the initial $\mathrm{CO}_{2}$ storage in living biomass (Gielen, et al., 2000). Replacing fossil fuels with sustainably-produced biomass will reduce the net emissons of $\mathrm{CO}_{2}$ to the atmosphere.

The modern kraft pulp mill uses fossil fuel for the operation of the lime kiln. Lime kiln is the biggest user of fossil fuels in kraft process and the only part of the pulp mill that needs substantial purchasing of fuel (Ikonen, 2012). The energy consumption of a modern kiln operating near to nominal capacity is typically in the range of 5.5 to 6.5 GJ per ton of reburned lime produced (Jarvensive, 2003). Lime kilns are an integral part of the chemical recovery system where the lime calcination occurs. Lime calcination is the process of converting lime mud (essentially $\mathrm{CaCO}_{3}$ ) generated in the causticizing plant to reburned lime $(\mathrm{CaO})$. This reaction is carried out in high temperatures in a rotary lime kiln, which is both a chemical reactor and heat transfer device (Green and Hough, 1992). Calcination required a minimum temperature of $815^{\circ} \mathrm{C}$ for calcinations to occur (Green and Hough, 1992).

Lime kilns is one sources of fossil fuelderived $\mathrm{CO}_{2}$ emissions (Miner and Upton, 2002). Common lime reburning kiln fuels are natural gas and fuel oil. Several attempts have been made to replace the fossil fuel (Ikonen, 2012), including using wood and bark powder, lignin, pyrolysis product, combustible gas from gasification process, and fuel from the pulp mills such as turpentine or methanol liquid, stripper off-gas (SOG), non-condensable gas (NCG), tall oil, and tall oil pitch. Gasification of wood, coal and other materials have been used for many years to provide clean fuel-gas for firing lime kilns. Good, stable operation is possible with gasification with production capacity and heat rate similar to that for natural gas. The advantage of gasification is that using the syngas is potentially more efficient than direct combustion of the original fuel because it can be combusted to produce higher temperatures. The other alternative energy resources studied here are coal, palm nut shell, and sludge from pulp mill. The use of those alternative solid energy resources may be implemented through a direct solid combustion or via gasification process followed with a gaseous combustion in the kiln. Each combustion techniques has advantages and disadvantages

This paper presents the thermodynamic simulation of the utilization of alternative energy resources to reduce natural gas consumption in the kiln, i.e. co-combustion of natural gas with sludge; co-combustion of natural gas with palm nut shell, co-combustion of natural gas with coal, co-combustion of natural gas with producer gases as product of gasification of coal, palm nut shell, or sludge. The use of those alternative solid energy resources are expected to be one of alternative energy resources in pulp mill to meet the national program on the energy mix in 2025 .

\section{MATERIALS AND METHOD}

This study dealed only with the thermodynamic simulation of alternative energy resources for the partial substitution of natural gas in supplying the heat of reaction and provides a high temperature (above $815^{\circ} \mathrm{C}$ ) in the calcinations process. A model of a complete gasification, combustion, and calcination processes was simulated in Aspen Plus v.7.1 and then linked to a reference kraft rotary lime kiln process. The alternative energy resources in this study included coal, palm nut shell and sludge cake from pulp mill. Partial substitution of natural gas with these solid fuels via direct co-combustion or producer gas via steam gasification were calculated based on heating value calculation, without regard to other combustion properties. 
Typical specification of rotary lime kiln based on one of mill's data in South Sumatera used in the model is presented in Table 1. Lime mud has $\mathrm{CaCO}_{3}=63 \%$; inert $=7 \%$; and moisture content $=30 \%$. Composition of typical natural gas from Indonesia and properties of several solid fuels of interest to the lime kiln are presented in Table 2. Sludge is a potential alternative energy resource in a kraft pulp mill with total generation about $95 \mathrm{~kg} /$ ton $\mathrm{CaO}$. Palm nut shell is another alternatives as renewable recources as well as coal, although coal is belong to the category of non-renewable recources.
To produce the producer gas with a medium heating value, it is necessary to develop a configuration of the gasification reactor. In this study, we proposed a configuration for steam gasification with separate reactor for combustion and that for gasification process (Figure 1). Heat for endothermic gasification reactions was supplied from combustion of solid fuel. The steam gasification of solid fuel was carried out in another fluidized bed reactor. This configuration can prevent air-derived $\mathrm{N}_{2}$ dilution into producer gas to produce medium heating value gas, and it is simpler and easier to be implemented (Pranolo and Susanto, 2010).

Table 1. Typical Spesification of Rotary Lime Kiln

(Derived from The Mill's Data from South Sumatera)

\begin{tabular}{lrl}
\hline Operating Conditions: & 380 & ton/day \\
\hline Production Rate & 1000 & ${ }^{\circ} \mathrm{C}$ \\
Product Temperature & 80 & $\%$ \\
Availability & 3 & $\%$ \\
Residual $\mathrm{CaCO}_{3}$ & & \\
\hline Firing Conditions: & natural gas \\
\hline Fuel Type & 34 & $\mathrm{MJ} / \mathrm{Nm}^{3}$ \\
LHV Natural Gas & $225 \quad$ & $\mathrm{Nm}^{3} /$ ton $\mathrm{CaO}$ \\
Natural Gas Consumption & 2 & $\%$ \\
Excess Air &
\end{tabular}

Table 2. Properties of Sludge Cake, Palm Nut Shell, Coal, and Natural Gas

\begin{tabular}{|c|c|c|c|c|c|c|}
\hline \multirow[b]{2}{*}{$\begin{array}{l}\text { Proximate } \\
\text { (db) }\end{array}$} & \multirow[b]{2}{*}{ Analysis } & \multirow[t]{2}{*}{$\begin{array}{l}\text { Sludge Cake from } \\
\text { Kraft Pulp Mill }\end{array}$} & \multirow[t]{2}{*}{$\begin{array}{l}\text { Palm Nut } \\
\text { Shell } \\
\end{array}$} & \multirow[t]{2}{*}{ Coal } & \multicolumn{2}{|c|}{ Natural Gas from Indonesia } \\
\hline & & & & & Component & $\begin{array}{l}\text { Mole } \\
\text { Fraction }\end{array}$ \\
\hline & Ash & $27.60 \%$ & $1.86 \%$ & $7.69 \%$ & $\mathrm{~N}_{2}$ & $1.50 \%$ \\
\hline \multicolumn{2}{|c|}{ Volatile Matter } & $61.00 \%$ & $76.59 \%$ & $47.68 \%$ & $\mathrm{CO}_{2}$ & $2.00 \%$ \\
\hline \multicolumn{2}{|c|}{ Fixed Carbon } & $11.40 \%$ & $21.55 \%$ & $44.63 \%$ & Methane & $94.00 \%$ \\
\hline \multicolumn{2}{|c|}{ Ultimate Analysis (db) } & & & & Ethane & $1.50 \%$ \\
\hline & Ash & $27.60 \%$ & $1.86 \%$ & $7.69 \%$ & Propane & $0.75 \%$ \\
\hline & $\mathrm{C}$ & $34.54 \%$ & $55.33 \%$ & $63.54 \%$ & n-Butane & $0.10 \%$ \\
\hline & $\mathrm{H}$ & $4.29 \%$ & $5.40 \%$ & $5.65 \%$ & i-Butane & $0.10 \%$ \\
\hline & $\mathrm{N}$ & $1.18 \%$ & $0.34 \%$ & $0.79 \%$ & n-Pentane & $0.01 \%$ \\
\hline & $\mathrm{S}$ & $0.36 \%$ & $0.07 \%$ & $0.25 \%$ & i-Pentane & $0.02 \%$ \\
\hline & $\mathrm{O}$ & $32.03 \%$ & $37.00 \%$ & $22.08 \%$ & Hexane & $0.01 \%$ \\
\hline & & & & & Heptanes & $0.01 \%$ \\
\hline \multicolumn{2}{|l|}{ Moisture } & $10 \%$ & $10 \%$ & $10 \%$ & $\mathrm{H}_{2} \mathrm{~S}$ & $35 \mathrm{ppm}$ \\
\hline \multicolumn{2}{|c|}{ LHV, MJ/kg (db) } & 14 & 21 & 25 & $\mathrm{LHV}, \mathrm{MJ} / \mathrm{Nm}^{3}$ & 34 \\
\hline
\end{tabular}




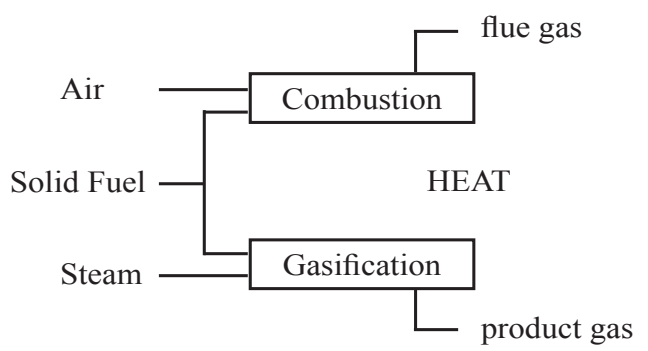

Figure 1. Steam Gasification Configuration with Separate Reactor for Combustion and That For Gasification
The scheme of co-combustion of natural gas with solid fuel integrated with calcinations process modeling is presented in Figure 2a and co-combustion of natural gas with producer gas integrated with calcinations process modeling is presented in Figure 2b. The process assumption were as follows.

a. The model neglected the influence of the physical properties of materials.

b. The model didn't distinguish the type of reactor associated with contacting the solidsgas.

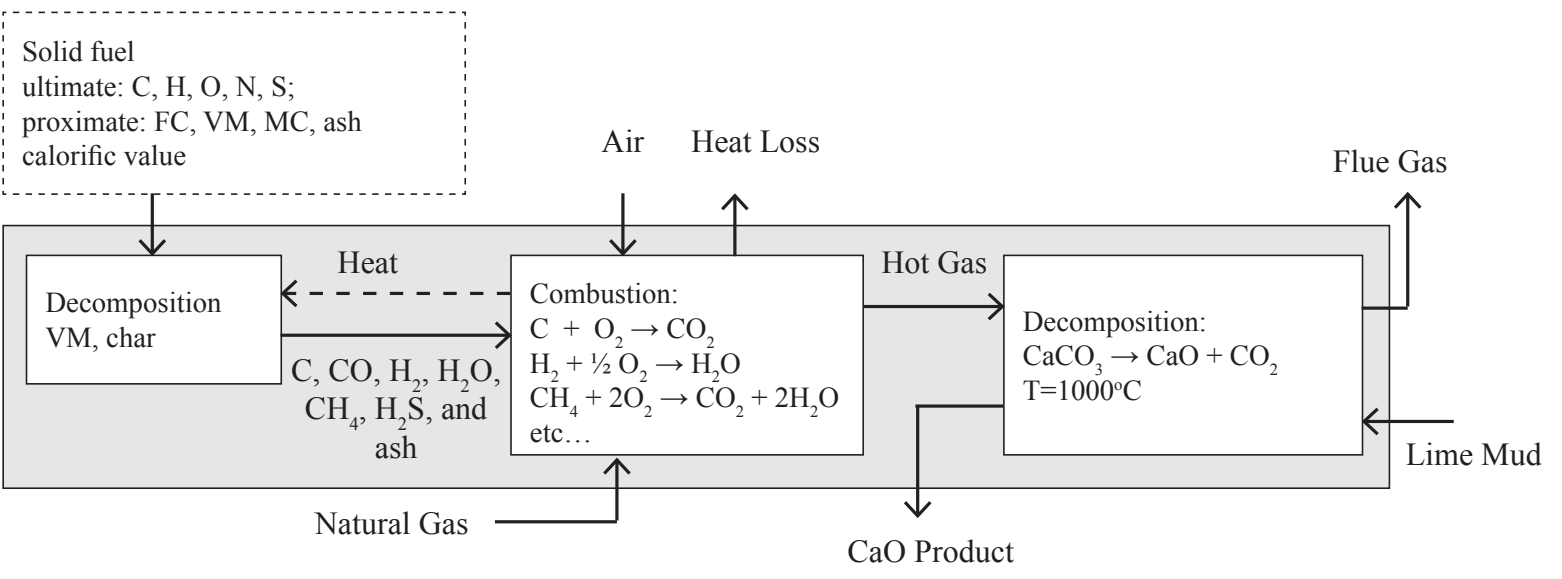

(a) Co-Combustion of Natural Gas with Solid Fuel Integrated with Calcinations Process

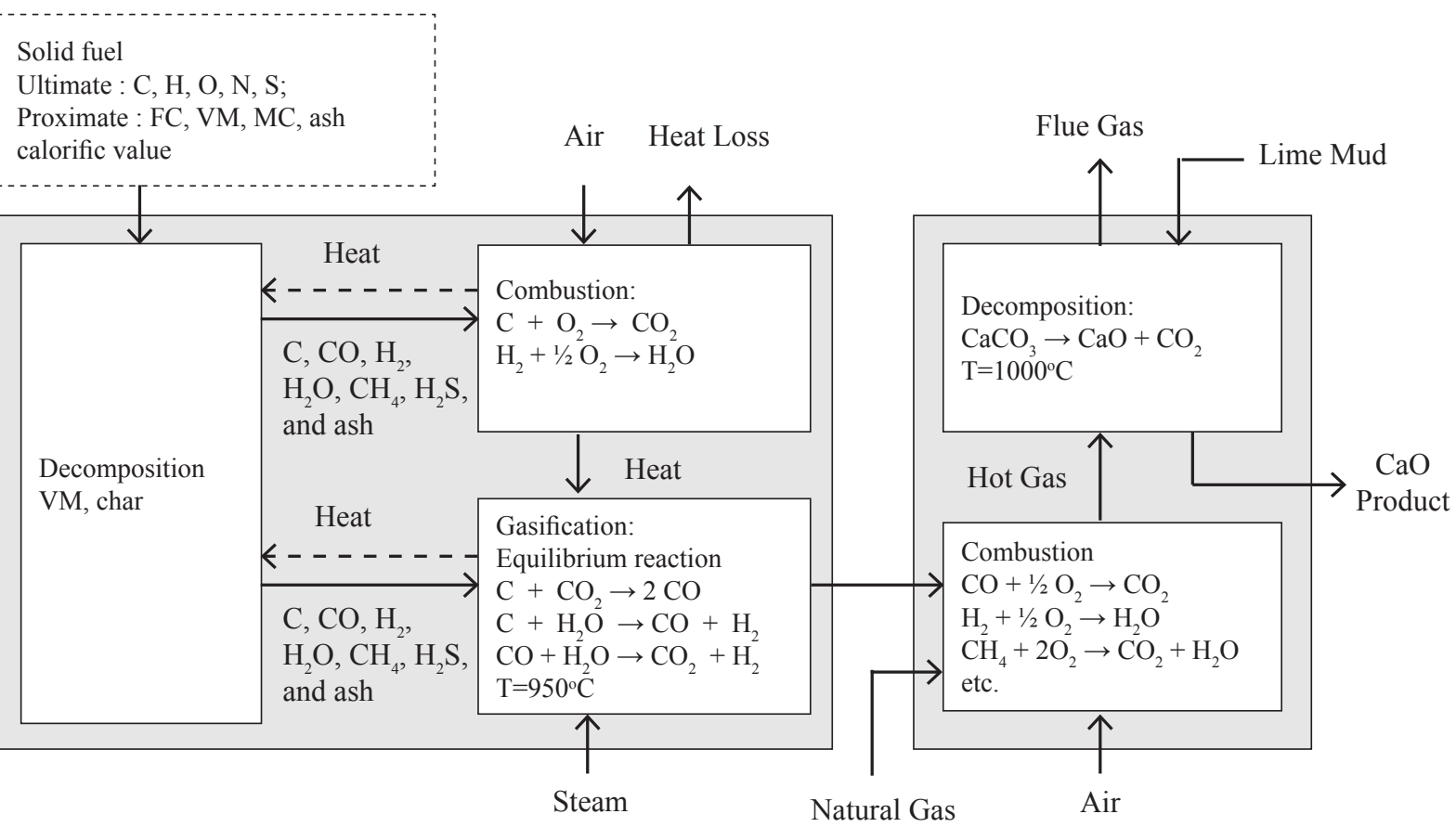

(b) Co-Combustion of Natural Gas with Producer Gas Integrated with Calcinations process

Figure. 2. The Scheme of Co-Combustion of Natural Gas with Solid Fuel or Producer Gas Integrated with Calcinations Process Modelling 
c. The model didn't take into account the reaction rate, heat transfer rate and mass transfer rate.

d. In the calciner, the fuel combustion and the raw material decomposition processes take place in two different reactor, i.e in combustor and calciner (Zhang, et al., 2011).

e. Only the decomposition of the calcium carbonate in the raw material was taken into account, and oxides like $\mathrm{SiO}_{2}, \mathrm{Fe}_{2} \mathrm{O}_{3}$, and $\mathrm{Al}_{2} \mathrm{O}_{3}$ were treated as inert (Zhang, et al., 2011).

f. All the reactions in kiln take place at the same temperature and can achieve equilibrium.

g. Heat loss was assumed of $2 \%$.

\section{RESULTS AND DISCUSSION}

\section{Steam Gasification of Solid Fuels}

Gasification process is a technology to upgrade solid fuels into gaseous fuel containing the following main combustible gas: $\mathrm{H}_{2}, \mathrm{CO}$, and $\mathrm{CH}_{4}$. In addition, the following gas may present in the gaseous fuel: $\mathrm{CO}_{2}, \mathrm{H}_{2} \mathrm{O}$ and $\mathrm{N}_{2}$. Gas composition depends on the elemental composition of the coal or biomass and the type of gasifying agent. Steam gasification has main reaction as follow: $\mathrm{C}+\mathrm{H}_{2} \mathrm{O}$ $-->\mathrm{CO}+\mathrm{H}_{2}$. Therefore, the concentration of $\mathrm{H}_{2}$ in the producer gas is higher. Producer gas can be processed into a relatively clean gaseous fuel as a substitute fuel in the lime kiln.

The effect of S/F (steam to solid fuel ratio) on gas composition and heating value of producer gas are presented in Figure 3. The addition of steam to the gasification process as the gasifying medium intended to enhance the formation of $\mathrm{H}_{2}$ gas but affect in decrease $\mathrm{CO}$ gas formation, based on homogeneous water shift reaction: $\mathrm{CO}$ $+\mathrm{H}_{2} \mathrm{O}-->\mathrm{CO}_{2}+\mathrm{H}_{2}$. Because heating value of $\mathrm{H}_{2}$ is lower than $\mathrm{CO}$, the overall heating value of producer gas decrease with $\mathrm{S} / \mathrm{F}$. The configuration separates the generation of heat from combustion reactions and heat consumption for gasification reaction. This configuration produces a medium heating value of producer gas because no$\mathrm{N}_{2}$ dilution from combustion air. From the simulation, steam gasification of sludge could produce gas with maximum heating value about $11 \mathrm{MJ} / \mathrm{Nm}^{3}$, palm nut shell produce gas with maximum heating value about $18 \mathrm{MJ} / \mathrm{Nm}^{3}$, and coal produce gas with maximum heating value about $19 \mathrm{MJ} / \mathrm{Nm}^{3}$. For comparison, natural gas in this study had heating value of $34 \mathrm{MJ} / \mathrm{Nm}^{3}$.
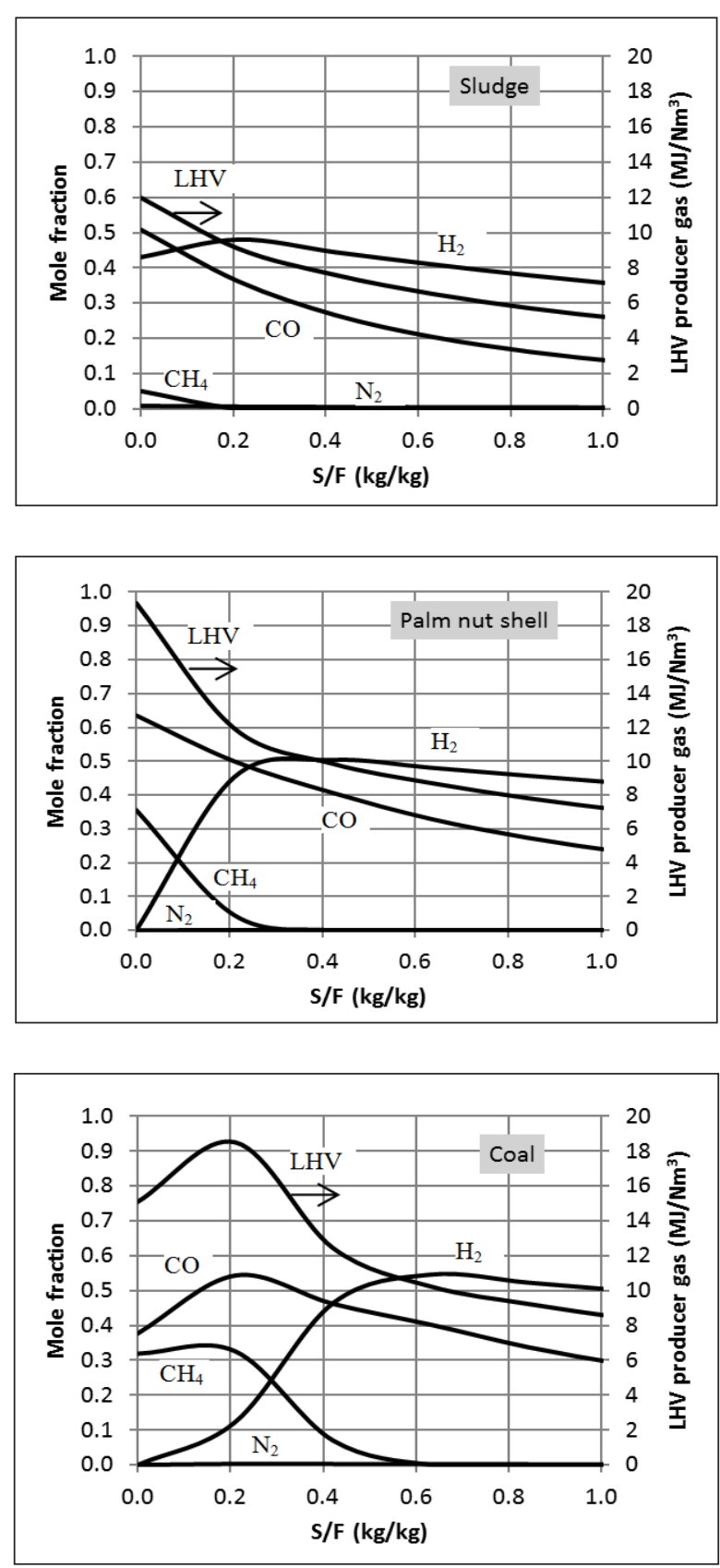

Figure 3. LHV and Producer Gas from Gasification of Coal, Palm Nut Shell, and Sludge

\section{Lime Kiln Fuelled with Natural Gas}

A minimum temperature of $815^{\circ} \mathrm{C}$ is required for calcination to occur, but temperatures over $1149^{\circ} \mathrm{C}$ result in overburnt lime with poor slaking properties, and also damage the kiln's refractory lining (Green and Hough, 1992). Thermodynamically, the calcination process is defined to take place perfectly at temperature above $800^{\circ} \mathrm{C}$ (Figure 4). Natural gas consumption 
was calculated according to heat and temperature requirements to achieve calcination reaction. Drying and heating up of lime mud was conducted by utilizing the hot exhaust gas which flowing in the opposite direction of lime in the kiln. In this simulation, calcination was carried out at $1000^{\circ} \mathrm{C}$ with natural gas consumption of $218 \mathrm{Nm}^{3} /$ ton $\mathrm{CaO}$ in condition no heat loss. Practically, natural gas consumption in one of kraft pulp mills in South Sumatera is about $225 \mathrm{Nm}^{3} /$ ton $\mathrm{CaO}$ with certain heat loss (the mill's data).

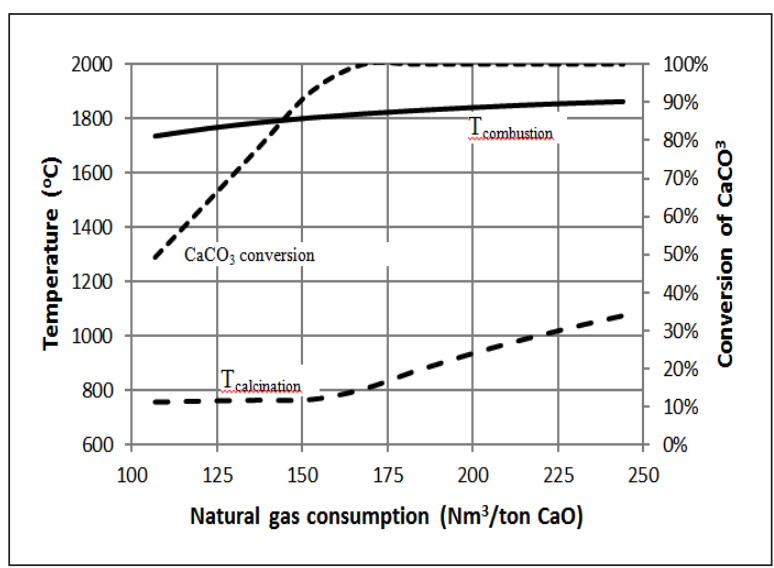

Figure 4. Natural Gas Consumption for Lime Calcination

\section{Lime Kiln Fuelled with Natural Gas and Solid Fuel Through Direct Combustion and Steam Gasification}

Effect of solid fuel specification consumption on natural gas saving is presented in Figure 5. With total generation about $95 \mathrm{~kg} /$ ton $\mathrm{CaO}$, sludge could save natural gas consumption until $20 \%$ through direct co-combustion. The portion of natural gas substitution is limited with the availability of sludge and the attainable combustion temperature. As comparison, co-combustion of natural gas with $95 \mathrm{~kg} /$ ton $\mathrm{CaO}$ of coal reduce the natural gas consumption by $37 \%$ and $95 \mathrm{~kg} /$ ton $\mathrm{CaO}$ of palm nut shell reduce by $30 \%$. Portion of coal and palm nut shell in co-combustion with natural gas may be more flexible in term of availability and energy, but care must be taken for impurities in co-combustion of solid fuel those may affect the quality of produced $\mathrm{CaO}$. Partial substitution of natural gas with solid fuel through direct cocombustion might be implemented through two types of burners, the burner for gas and burner for pulverized solid fuel.
Via steam gasification, sludge could save natural gas consumption until $18 \%$. The use of sludge and other solid fuel via steam gasification are limited with the attainable combustion temperature, because heating value of producer gas is lower than that of natural gas. As comparison, co-combustion of natural gas with producer gas from $95 \mathrm{~kg}$ of coal reduce the natural gas consumption by $34 \%$ and producer gas from $95 \mathrm{~kg}$ of palm nut shell reduce by $27 \%$. In contrast to the direct combustion of solid fuel, the gaseous fuel from gasification may be used in a lime kiln with a less modification of the burner section.

The difference in the composition of the natural gas, solid fuel, and producer gas will lead to differences in combustion characteristics. Characteristics of gas fuels include the following parameters: gas composition, heating value, combustion air requirements in relation to the supply of air system and flue gas stack, attainable combustion temperatures, flame characteristics, characteristics of burner, flame speed and flammability limits, impurity content specifically required by the gas users, and the concentration of tar. Since the heating value of producer gas is relatively lower than that of natural gas, replacement natural gas with producer gas may result in the following: increases fuel gas flow rate, need to redesign the gas flow system, decreases air/fuel ratio, need to recontrol air/fuel ratio, decrease heating rate, and need to redesign burner and furnace.

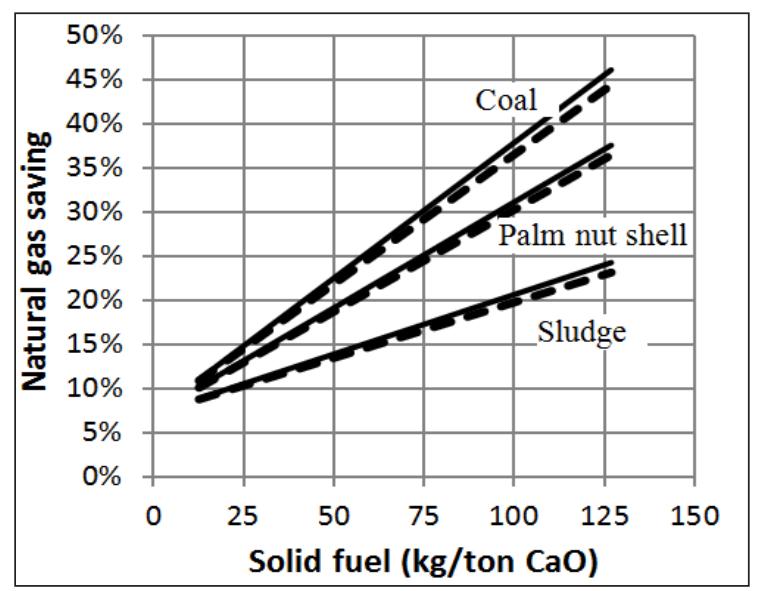

----- Direct Combustion of Solid Fuel

- - Steam Gasification of Solid Fuel

Figure 5. Natural Gas Saving for Lime Kiln Fuelled with Natural Gas and Solid Fuel 
Emission of Interesting Pollutants in CoCombustion of Natural Gas with Solid Fuel

Among the alternative fuels, the sludge has a highest ash content of $27.60 \%(\mathrm{db})$, followed by coal with $7.69 \%$, and palm nut shell with $1.86 \%$. Combustion of sludge release highest $\mathrm{SO}_{\mathrm{x}}$ and ash, followed by coal, and palm nut shell (Figure 6) (see our simulation in [Syamsudin and Susanto, 2012]).
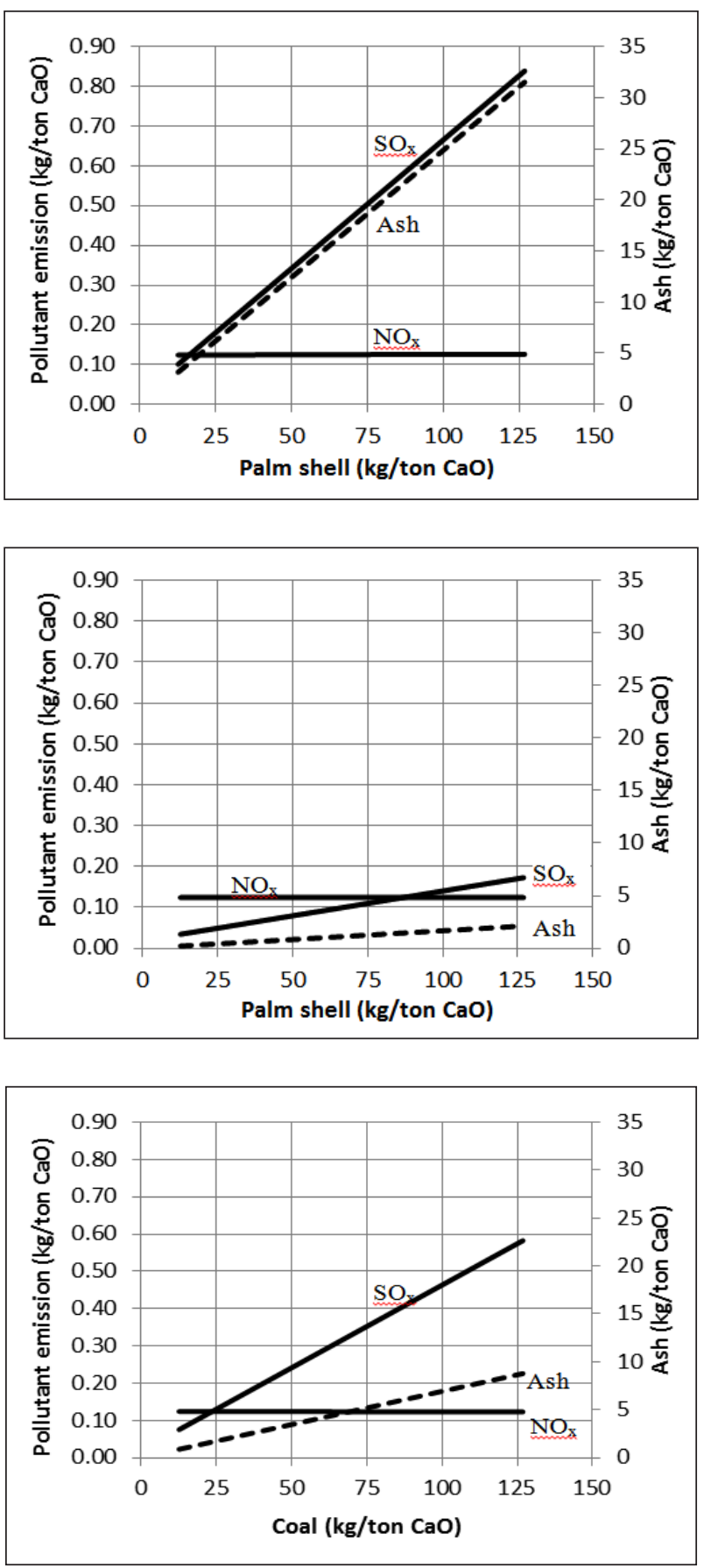

Figure 6. Emission of Interesting Pollutants in Co-Combustion of Natural Gas with Solid Fuel
The high ash on the sludge may come from the inherent inorganic wood, additives in the pulping process, as well as inorganic materials in the wastewater treatment process. Increased consumption of solid fuel affects in an increase the amount of ash that must be addressed. Ash affect on the particulate emissions and also can cause problems due to slagging, deposit formation, corrosion, and lime product contamination. The fusion and agglomeration of ash particles in the fuel beds can lead to poor combustion and calcinations conditions, and problems with ash removal and downstream ash handling equipment.

Producer gas can then be processed into a clean gaseous fuel to substitute natural gas in the lime kiln. The gasification process produces ash-free gas after passing through the separation process, and decreasing quality of lime products due to ash contaminants can be minimized. In addition, the high-temperature process refines out corrosive ash elements such as chloride and potassium, allowing clean gas production from otherwise problematic fuels.

\section{CONCLUSIONS}

Based on our thermodynamic calculation, steam gasification of coal, palm nut shell and sludge might produce gaseous fuel with heating value of 19,18 , and $11 \mathrm{MJ} / \mathrm{Nm}^{3}$ respectively. Calcination at $1000^{\circ} \mathrm{C}$ consume natural gas about $240 \mathrm{Nm}^{3} /$ ton $\mathrm{CaO}$. With total generation of sludge $95 \mathrm{~kg} /$ ton $\mathrm{CaO}$, co-combustion natural gas with sludge could save natural gas until $20 \%$ and higher for coal and palm nut shell. The portion natural gas substitution is limited with the availability of sludge and the attainable combustion temperature. Care must be taken for impurities in direct combustion of solid fuel those may affect the quality of produced $\mathrm{CaO}$. Co-combustion of natural gas with producer gas of sludge could save natural gas until $18 \%$ and higher for coal and palm nut shell. The limitation of utilization solid fuels via gasification is on the attainable combustion temperature.

\section{ACKNOWLEDGEMENTS}

This study was financially supported by doctoral scholarship program by Ministry of Industry, Republic of Indonesia year of 2012. 


\section{REFERENCES}

Gielen D. J., Bos AJM, de Feber MAPC, Gerlagh T. 2000. Biomass For Greenhouse Gas: Task 8: Optimal emission reduction strategies for Western Europe.

Green R.P., Hough G. 1992. Chemical Recovery in the Alkaline Pulping Processes. $3^{\text {rd }}$ ed. TAPPI Press. Atlanta.

Gustavsson L., Borjesson P., Johansson B., Svenningsson P. 1995. Reducing CO, Emissions by Substituting Biomass for Fossil Fuels. Energy, 20: No. 11: p.1097-1113.

Gustavsson L., Svenningsson P. 1996. Substituting Fossil Fuels with Biomass. Energy Convers. Mgmt, 37: Nos 6-8: p.1211-1216.

Ikonen O. 2012. Alternative Liquid Biofuels for Lime Kilns. Bachelor' Thesis, Lappeenranta University of Technology.

Jarvensivu M. 2003. Intelligent Control of the Lime Kiln Process with Respect to Environmental Requirements. Dissertation. Helsinki University of Technology.

Miner R, Upton B. 2002. Methods for Estimating Greenhouse Gas Emissions from Lime Kilns at Kraft Pulp Mills. Energy, 27: 729-738
Pranolo S. H., Susanto H. 2010. Kajian Termodinamika Konfigurasi Reaktor Gasifikasi untuk menghasilkan Gas Sintesis. Proceeding on Seminar Nasional Soebardjo Brothohardjono VII. Surabaya.

Syamsudin, Susanto H. 2012. Evaluation on Potential Emission of Gaseous Polutants in Utilization of Sludge Cake from Pulp Mills for Alternative Energy Resources. Proceeding on the 19th Regional Symposium on Chemical Engineering. Bali.

Zhang Y, Cao S. X., Shao S, Chen, Y, Liu S.L., Zhang S. S. 2011. Aspen Plus-Based Simulation of a Cement Calciner and Optimization Analysis of Air Pollutants Emission. Clean Techn Environ Policy, 13:459-468.

http://www.esdm.go.id/batubara/doc download/714-blue-print-pengelolaanenergi-nasional-pen.html. Kementerian energi dan sumber daya mineral. Blueprint pengelolaan energi nasional 2006-2025. Accessed July 2012. 